\title{
Synthesis on Narrowing the Gap between Engineering Education and Industry through Science, Technology, Economics, Management and 'Fire Fighting' (STEMF)
}

Vedhathiri Thanikachalam,

Former Professor and HOD, Center for

International Affairs, NITTTR, Chennai

Vthani2025@gmail.com

\section{Abstract}

India globalized its economy in 1991 and thousands of

MNCs have established their design and manufacturing centers in India by fully utilizing the human capital developed by the Indian universities, institutions, manufactured the state- of- the- art technology products and successfully exporting them world- wide markets. Till today no company has closed its design or production center in India for want of high performing, motivated and risk-taking engineers since the availability is ten times the need of the growing industries.

However, the global industries have to meet the challenges due to Industry-4 and train their employees through various proven models like 'learning organization', 'just in time learning model', etc. The accreditation of engineering programs has been undertaken to ensure the high quality in the graduates. Continuous improvements in Teaching-Learning Process are being implemented by the engineering institutions. Certain percentage of faculty members are being continuously trained through Quality Improvement Programs of Ministry of Human Resource Development (MHRD), but the shortage continues due to fresh appointment of raw graduates who were not trained in any area of engineering education. The vacancies arise day by day. Modernization of labs and workshops are being carried out through 'Modrob' (Modernization and Removal of Obsolesce) scheme of AICTE and the state Directorates of Technical Education and only in government and assisted engineering colleges. Around 800 colleges were closed as per AICTE order for their deficiencies. World Bank Assisted Technical Quality Improvement (TEQIP) Projects' capacity development has been implemented in all government, governments assisted colleges and in a few self-financing colleges only. Further, quality improvement of the curriculum and efficiency improvement in decision making, examination reforms, research work, etc. have been completed for the benefit of state technical universities and autonomous government assisted colleges only. Many research studies indicate that the curricula have to be improved and modernized. Centers of Excellence and Innovation have been established in a few institutes of national importance only. Industry- Institute- GovernmentSociety-Partnership Centers have also been established mostly in National Institutes of Technology and institutes of national importance. Industrial training of the engineering students has been implemented in few institutes only. Dual programs have been introduced in the institutes of national importance. Finishing school courses are being introduced only in very few selffinancing engineering colleges. The gaps between the curriculum and the industrial needs have been continuously narrowed only in state technical universities, National Institutes of Technology (NIT) and institutes of national importance. However, many disruptions like Industry-4, and digital technology demand for industry ready engineers in emerging technologies but the majority of the output from self-financing engineering colleges do not possess the needed skills and competencies. India is emerging as a Center for Design of Innovative Products and Services.

A mega model to improve the skills and competencies of the engineers through a smart five theme approach has been developed which focuses on Science and Arts of Curriculum Development, Educational Technology, Educational Economics, Educational Management and needed 'Fire-Fighting Model' to meet the new gaps due to the disruptive digital technology which demands dynamism in all players. An exhaustive list of subthemes for each- major theme has been reviewed, researched and presented. There is a need for further in-depth research on closing the gap between the producers and consumers of human capital in India.

KEYWORDS: Closing the gap of performance of the graduates, Curricula have to be modernized, 'Five Theme Mega Model', Industry specific curriculum development, Adoption of digital technology, Industry-Institute-GovernmentSociety Partnership.

\section{Introduction}

India ranks third in the production of engineering graduates in the world. State technical universities, National Institutes of Technology, 
affiliated colleges, deemed to be universities, government engineering colleges and private self-financing engineering colleges are producing these graduates with varying degrees of skills and competencies. All India Council for Technical Education, Indian Society for Technical Educational and National Institutes of Technical Teachers Training and Research are continuously contributing to the quality improvement of the curriculum and faculty development.

There is a need for sufficient capital for dynamic planning the infrastructure and resources for modernization and removal of obsolesce in the labs and workshops in $80 \%$ of the engineering colleges. The employers should plan and implement needed training programs to introduce company specific skills and competencies in the courses. They can also plan appropriate advanced competency- based training periodically to meet their growing needs for modernizing their production processes and services through their Executive Development Centers in collaboration with the technical universities, The Association of Employers can further collaborate with the engineering institutes on a long-term basis for planning industry specific programs, dissertations and sponsored research and development projects. However, it is recommended to continuously modernize the curriculum design and instructional planning and complement the skills needs of the graduate through a series of a tracer studies, impact studies and in-depth consultation with the employers. There is no short-cut solution to narrow the growing gaps between "the producers and consumers of human capital".

The following are the major developments in meeting the gaps in human capital: 1. Need for Dynamic Curricula based on the Needs Analysis due to Emerging Technologies, Tracer Studies, and Faculty Development [5, $11,23,24,27,35,36,37,39,46,50,59,56,57$, $58,61,62,66,68,74,75,76,78,82,86,87$, $107,115,118,134,135,137,156]$.

2. Many existing curricula have to be modernized to meet the challenges of the fast- growing industries.

3. Introduce creative faculty engagement and quality improvement through continuous improvement in the instructional design and delivery.

4. Meeting the fast growth of industries due to advancements in digital technology.
5. Meeting the fast challenges in the skill requirements due to impact of disruptions.

6. Planning outcome- based curriculum with industry participation, formative evaluation and improvement.

7. Establishing dynamic linkages with the consumers of knowledge capital (employers and entrepreneurs).

8. Reversed system for planning the interdisciplinary programs based on the desired outcome (Skills, Competence and Abilities).

9. Introducing flexible programs with built-in industrybased training and internship/ cooperative programs.

10. Offering industry- specific courses through a consortium of engineering colleges and sponsored dissertation.

11. Providing continuing education courses and finishing school programs.

12. Performance improvement through task- specific inhouse training of the faculty members.

13. Planning hybrid courses through prescribing needed MOOCs under Swayam of MHRD, Coursera, edX, WBI, etc.

14. Introducing large scale strategic planning of engineering institutes.

15. Facilitating the undertaking of Sponsored Research Projects from the industries.

However, the gaps between the skills, competencies and the needs of the employers always increase due to dynamism of industrial growth. Hence, there is an urgent need to focus on the problems and solutions to narrow the gap between the engineering institutes and the industry.

\section{Objectives of the Research}

To evaluate the needs of various engineers at different categories of their career needs

To review the contribution of the professional associations and government sponsored research, training and development organizations.

To assess the initiatives of the engineering colleges in modernizing the curricula and developing the abilities of the graduates.

To suggest needed collaboration and cooperation between the producers and consumers of human capital. 
To review the global practices in developing market ready engineers.

To suggest needed accelerated programs and courses to narrow down the gaps that being sensed due to Industry-4 through fire-fighting model.

\section{Literature Survey}

Quality of Industrial Demand for the Engineering and Technology Graduates

1. Entry Level Jobs: Total responsibility of the engineering institutes.

2. Middle Level Jobs: Through the in-house training and learning on the job, continuous process improvement.

3. Senior Level Jobs: Through the challenges and coaching and mentoring, in-house management training and cooperation with the leaders from research organizations, universities and centers of excellence.

4. ' $C$ ' Level Jobs: Through the leadership development, exposure to global challenges.

The skills that are required by Engineering Graduates at the Entry Level:

According to School of Engineering Education, Purdue University [50], the aim of the graduate competencies is to help each student develop the ability to:

- $\quad$ Create and synthesize knowledge

- $\quad$ Master written and oral communication skills

- Think critically and reflectively

- Demonstrate engineering skills

- $\quad$ Engage the professional development

- Participate actively in professional field or engineering education

- $\quad$ Teaching engineering

- And apply their knowledge of instruction, curriculum design, and assessment of engineering science, problem solving, and design appropriately.

Employability skills (Kazilian et al., 2009) [ 33]

- $\quad$ Personal quality skills

- $\quad$ Basic skills

- Thinking skills

- $\quad$ Resource /capability skills

- $\quad$ System technology skills

- Information skills

- $\quad$ Personal quality skills (Responsibility, Selfconfidence, Self-management, Sociability, Honesty, Punctuality and efficiency, Adoptability and flexibility, Self-control, Selfdirected, and Good work attitude)
Ac According to Zaharim et al. (2010) [181] the expected skills from the graduates are:

- Ability to function as an individual and in a group with the capacity to be a leader or manager as well as an effective team member

- $\quad$ Ability to communicate effectively, not only with engineers but also with the community at large

- Ability to undertake problem identification, formulation and solution

- $\quad$ Ability to acquire and apply knowledge of engineering fundamentals

- Having competency in engineering application and orientation

- $\quad$ Ability to utilize a systems approach to design and evaluate operational performance

- $\quad$ Recognizing the need to undertake lifelong learning, and possessing/acquiring the capacity to do so

- $\quad$ Ability to design and conduct experiments, as well as to analyze and interpret data

- Having the competency in theoretical and research engineering

- Having in-depth technical competence in a specific engineering discipline

- Having social awareness, cultural, global and environmental responsibilities and ethics of a professional engineer and the need for sustainable development

- Having the knowledge of entrepreneurial skills

Azevedo et al. (2012) [12] Proposed a set of following competencies of business graduates:

- $\quad$ Competency of critical and analytical analysis

- $\quad$ Teamwork and relationship building among influencing and persuading

- $\quad$ Critical/analytical skills

- $\quad$ Self and time management

- Leadership

- Ability to see the bigger picture

- $\quad$ Presentation and communication.

Shukla and Suresh Garg (2016) [58] presented the following attributes to assess the Industry needs:

- $\quad$ Engineering knowledge

- $\quad$ Problem analysis

- Design/ Development of Solutions

- Ability to conduct investigation of complexproblems

- Modern tool usage

- $\quad$ Synergy between Engineering and Society

- $\quad$ Environment and Sustainability

- $\quad$ Ethics 
The competencies desired to get accreditation from ABET (2017) [4, 12, 18]:

(a) An ability to apply knowledge of mathematics, science and engineering

(b) An ability to design and conduct experiments, as well as to analyze and interpret data

(c) An ability to design a system, component, or process to meet desired needs

(d) An ability to function on multi-disciplinary teams

(e) An ability to identify, formulate, and solve engineering problems

(f) An understanding of professional and ethical responsibility

(g) An ability to communicate effectively

(h) The broad education necessary to understand the impact of engineering solutions in a global and societal context

(i) A recognition of the need for, and an ability to engage in life-long learning

(j) A knowledge of contemporary issues

(k) An ability to use the techniques, skills, and modern engineering tools necessary for engineering practice.

EU European Network for Accreditation of Engineering Education (2017) [23]

\section{Program Outcomes}

- $\quad$ Knowledge and understanding

- $\quad$ Engineering analysis

- $\quad$ Engineering design

- Investigations

- $\quad$ Engineering practice

- $\quad$ Making judgements

- Communication and team-working

- Lifelong-learning

According to EU Network for Accreditation of Engineering Education [21, 22], candidates who wish to take Work based Blended learning programs should have:

- Self- motivation

- $\quad$ Good time management

- $\quad$ Self- discipline

- Capability to read for comprehension

- $\quad$ Ability to set sights on an end result

- Confidents in being academically able

Work- based Blended Learning Success Criteria:

- $\quad$ Ability to overcome obstacles and not to give up easily

- Responsibility of one's own education- what one's learning is ultimately his own responsibility

- Willingness to try something new
- Willingness to work in a non-structured environment

- Willingness to express opinion in writing

- Willingness to

- $\quad$ actively participate in the learning process by doing tasks, projects, etc.

Top10 Skills in 2020 according to World Economic Forum [181]:

- $\quad$ Complex Problem Solving

- Critical Thinking

- Creativity

- $\quad$ People Management

- Coordinating with Others

- Judgement and Decision Making

- Negotiation

- $\quad$ Cognitive Flexibility

Verbal Skills [24]

- $\quad$ Global Communication Skills

- Effectively communicate across cultures, including foreign language proficiency

- Global Insight

-Understanding and acceptance of different cultures, religions, economies, governments, and global iss

- $\quad$ Self-Initiative

-Capacity to take risks and not stand on the sidelines

- Global Perspectives as well as the perspectives of others

The ability to communicate one's own perspectives

\section{QAA M-Level Descriptors}

Knowledge

- $\quad$ Systematic \& Comprehensive Understanding

- Originality in application

- $\quad$ Conceptual \& Critical Evaluation

Skills

- Operational

- Cognitive

- Transferrable

\section{UK- SPEC}

- $\quad$ Engineering Knowledge

- $\quad$ Problem Solving

- Leadership

- Interpersonal Skills

- $\quad$ Professional Standards

University-Industry Collaborations in Developing Countries

Jose Guimon (2013) [28] reviewed the process of university-Industry collaboration in developing 
countries. According to him collaboration between academia and industry is increasingly a critical component of efficient national innovation systems. It is useful to examine the experience of developed countries to better understand the different types of universityindustry collaboration, motivations to form these agreements and barriers to cooperation, as well as the role of public policy in fostering such linkages. Developing countries face even greater barriers to such alliances, calling for a differentiated approach to promoting university-industry collaboration. Joseph Mutale (2015) [29] concluded that strong links between engineering faculties and industry is the hey to transforming education in Africa. According to a Royal Academy of Engineering Study (2012) [54] sufficient engineering capacity is essential and social development of any country. It is a basic requirement for the provision of infrastructure that enables better healthcare, access to education and the development of an attractive environment for foreign investment. It is a key driver for innovation and growth.

Initiatives taken by Indian Software Industry [66, 64, 65]:

Most of the software companies started recruiting all needed engineers from all types of engineering branches and later offered needed software training for about six months and included them in the workforce. They never complained about the quality of the graduates. They became world class organizations through continuous improvements in software skills and competencies. They also recruited science students who have undergone bachelor programs in computer science and computer application. They filled the gaps through their in-house training.

Initiatives of Automobile Manufacturers [69, 67, 68, 72]:

Most of the automobile manufacturers started recruiting the needed employees from the engineering colleges, polytechnics and industrial training institutes and oriented them towards their needs. Most of the automobile manufacturing companies have also established training units and executive development centers to train their engineers and workmen.

\section{Initiatives of State Highways Department}

There was a severe shortage of civil engineers, but the State Highways Department recruited the mechanical engineers and conducted six months training program to develop them in planning and construction of highways.

Initiatives of State Public Works Department (PWD) [94]:

The State PWD has established four Staff Training Colleges in Chennai, Madurai, Tiruchirappalli, and Salem to continuously train their engineers at various levels to meet the desired skills and competencies.

The Initiatives of Chennai Metropolitan Water Supply and Sewerage Board established a Training Center in Chennai to train their engineers to meet desired skills. These departments received assistance from various international development agencies in establishing training enters.

\section{Initiatives of Indian Railways}

Indian Railways have established "Indian Railway institute of Civil Engineering, Pune" [www.railnews.in/category.in/rail-

institute/indian-railway-institute-of-civilengineering-iricen/pune/] for training the railways engineers. No engineering college offers in-depth professional program to meet the needs of railways but they offer advanced postgraduate programs in transportation engineering, transportation system design, foundation engineering, bridge engineering and structural engineering.

\section{Indian Cement Manufacturing Companies [94]:}

Cement manufacturing companies have established Regional Training Centers at ACC Jamul, Madhya Pradesh, JK Cements, Rajasthan, Gujarat Ambuja Cement in Gujarat and Dalmia Cement (Bharath) at Dalmia Puram, Tamil Nadu to train their engineers and workmen through World Bank- DANIDA-CMA-HRD project. Many other cement manufacturing companies have established dedicated training centers to improve the quality of cement, and reduce the cost of production and use of energy. They are to insure the environment in and around mines and manufacturing units.

State Governments' Initiatives [90, 92, 93]:

Many state governments established training organizations in management for their employees. State government of Kerala has established autonomous organizations (Management for Government) to train their employees in various locations in Kerala and Tamil Nadu has established a management training institute in Chennai. State pollution 
control department has established a lead training center in Chennai and Karnataka State has established its own training center in Bangalore. For Water Management/ Irrigation Management/Water Resource Development and Management most of the state governments have established many focused research and development centers to train the agricultural scientists, irrigation engineers and formers. Many state governments availed services and the cooperation from United States' International Development Agency (USAID).

Indian Society for Technical Education (ISTE) [www.isteonline.in]

This Society offers summer and winter schools through leading institutes to train the faculty members of polytechnics and engineering colleges and receives grants-in-aid from the government. It also conducts workshops. state and national seminars for the advancement of knowledge. Further, it brings a peer reviewed quarterly journal for publishing research articles from the faculty members. ISTE has a large number of state units and institute centers in engineering colleges and polytechnics. It recognizes the excellence in technical education and reward the best outcomes.

\section{Indian Geotechnical Society (IGS) www.igs.org.in/portal]}

This is a professional association of civil engineers and publish a journal and conducts national seminars and international conferences on the advancements of in this field. The state centers conduct monthly meetings on the advancement of knowledge and field practices. It conducts meetings and seminars through state centers.

Indian Society for Training and Development (ISTD) [www.istd.co.in]

This Society offers Diploma in Training and Development to meet the needs of the Indian industry. It also publishes research articles to meet the needs of the profession. It has established state centers to conduct monthly meetings and state seminars in training and development. It also brings a journal for publishing the developments of the Indian researchers in human resource management. There are many other associations in this area that offer training programs in human resource management.

\footnotetext{
Institution of Engineers (India) [www.ieindia.org/webui/iei-home.aspx]
}

This is one of the largest associations of Indian engineers started even before country got independence. It has got many divisions and publish journals on the advancement of the knowledge. It offers Associate Membership by conducting courses and examinations. It conducts a large number of conferences and seminars for the benefit of the professional members.

Boards of Apprenticeship/ Practical Training (BOAT) in Chennai [http://www.boatsrapprentice.tn.nic.in] Mumbai, Kolkata and Kanpur

Ministry of Human Resource Development has established four centers to provide training to the vocational students, technicians and engineering graduates through industries. Around 12000 to 15000 graduates are being trained and now these organizations would also train the non-engineering graduates.

Focused Growth on the Skills and Competencies of Engineers to Create Knowledge Capital

Even though many efforts concurrently are being taken by the government agencies and private sector, the problem of gap increases between the engineering institutes and the needs of fastgrowing industries due the impact of disruptive technologies. The gaps have to be researched to identify the steps to narrow the gaps that can be taken efficiently and effectively.

The Engineer of the Future (University of Colorado, 2001) [170]:

The engineer of the future applies scientific analysis and holistic synthesis to develop sustainable solutions that integrate social, environmental, cultural, and economic systems.

\section{Transformation Model of Engineering Education} $[136,142]:$

- Unleashes the human mind and spirit for creativity and compassion

- $\quad$ Expands engineers' professional and personal commitments to include both technical and nontechnical disciplines

- Inspires engineers to embrace the principles of sustainable development, renewable resources management, appropriate technology, and systems thinking

- $\quad$ Prepares engineers for social, economic, and environmental stewardships.

THE TRIPLE HELIX MODEL OF INNOVATION (Henry Etzkowitz, James Dzisah, Marina and Chunyan Zhou, 2007) 
In a knowledge-based society, university, industry and government have equal roles and form a triple helix in stimulating innovation. A stable regulatory framework is a necessary but not sufficient condition. The transformation of a university from teaching to a research and thence to an entrepreneurial institution is vital. Government must help to support the new developments through changes in the regulatory environment, tax incentives and provision of public venture capital. Industry takes the role of the university in developing training and research, often at the same high level as universities. If knowledge-based industries are lacking, university-government interactions can help jump-start their creation; if they are present, they can help expand their growth.

\section{RESEARCH METHODOLOGY}

1.To identify the major causes that create gaps between the engineering graduates who complete outcome- based engineering programs and the skills needed by the employers through the synthesis of the articles already published by researchers.

2.To assess the role of professional associations and their contributions to the advancement of human capital. 3.To suggest an accelerated engineering education process in developing courses and programs to meet the disruptions in meeting the needs of the employers

4. The whole research is based on the naturalistic model as advocated by Egon. G. Guba (1987) [16].

\section{SWOT ANALYSIS}

\section{Strengths}

- $\quad$ Around 4000 engineering colleges, 23 IITs, 10 IIITs, 7 IISERs, 31 NITs, 3 SPAs, 367 State Universities, 49 Central Universities, 282 Private Universities and 137 Deemed Universities offer degrees, postgraduate degrees and doctoral degrees in engineering and technologies.

- $\quad$ Around 200000 faculty members are serving these institutions.

- Around 1million graduates come out these institutes per year.

- $\quad$ Four NITTTRs to provide dedicated academic consultancy services with state extension centers

\section{Weaknesses}

- $\quad$ Approximately $90 \%$ of the faculty have not undergone any significant training in curriculum design, measurement, evaluation, instructional materials development, internal revenue generation, institutional development etc.

- $\quad$ Around $85 \%$ do not have Industry-InstitutePartnership

- Most of senior faculty have not gone for industrial training.

- Outcome- based curricula have not been implemented in all branches and in all institutions.

- $\quad$ Limited linkage with the industries.

- $\quad$ Poor employability skills and competencies of the graduates.

- $\quad$ There is a severe shortage of qualified and experienced faculty members.

- $\quad$ Competent and innovative faculty are discarded due to unending corrupt practices.

- Too much of corruption in higher educational administration.

- $\quad$ There is a severe shortage of motivated teachers with doctoral degrees.

- The curricula are not continuously updated.

- $\quad$ Limited industry focused research work.

- Innovation is discouraged by a large number of educational administrators.

- Minimum linkage with the industries for placement of the graduates.

- $\quad$ Limited funding for engineering education which results in 35 to $50 \%$ vacancies in engineering colleges and newly established IITs.

- $\quad$ Poor academic leadership.

- Poor ecosystem obstructs accelerated high performance.

- Weak research programs.

- Profit based educational organizations flourish.

- Less patents from the engineering institutions.

\section{Opportunities}

- Globalized economy that needs more competent engineers.

- $\quad$ Fifth largest economy in the world which needs competent engineers.

- More MNCs prefer India for design and manufacturing of products and global services.

- Growing space for Indian companies using the Indian engineers.

- $\quad$ More global opportunities for quality products.

- More space for innovations in digital technology.

- Indian human capital has been recognized in many advanced countries based on their highquality performance.

\section{Threats}


- Competition from fast- growing Asian Countries (China, Japan, and South Korea).

- More underemployment of the engineering graduates which causes low return on investment.

- Loss of income to the engineering graduates through poor salaries creates burden on their families to repay the bank loan.

- $\quad$ Flooding the design and product development by expatriates.

- $\quad$ Industry-4 demands for high quality innovators which is not recognized by many educational leaders.

\section{Where is the Focus?}

The initiatives to be taken by the engineering institutes, technical universities and the Ministry of Human Resources Development (Ministry of Education) through four major themes and sub themes are presented in the following section:

\begin{tabular}{ccrr} 
THEME-1: & SCIENCE & AND ARTS OF & AN \\
CURRICULUM & \multicolumn{2}{c}{ DEVELOPMENT } \\
THROUGH & NEEDS & ANALYSIS, \\
FORMATIVE & AND & SUMMATIVE \\
EVALUATION & &
\end{tabular}

The subthemes are based on the best global practices and the research work done in India presented in the following section:

The following suggestions are based on the outcomes of research works in Building Technology, Civil Engineering, Computer Science and Engineering, Embedded Technology System Engineering, Forestry, Instrumentation, Manufacturing Technology, Mechanical Engineering, Wood Technology [ 35, 36, 73, 74, 76, 57, 58, 103, 104, 105, 107, 112, 67, 68, 69, $61,62,87,93$ ].

Subtheme:1.1 Entrepreneurs' and Employers' Needs Analysis [1, 14, 16, 17, 23, 27, 33, 35, 36, 37, $39,40,46,50,53,54,56,57,58,59,61,62,64$, $66,87,69,73,74,76,78,80,82,86,87,89,91$, 93, 92, 96, 100, 105, 112, 115, 118, 129, 132, $134,135,136,137,149,160,172,173]$ :

- $\quad$ Analyze the needs of employers and design the curriculum. instructional delivery, assignments, tests, projects, research and product development.

- $\quad$ Conduct formative analysis and summative analysis through a set of representatives of employers, alumni, and faculty members.

Subtheme: 1.2 Planning needs-based courses (Basic Courses, Applied Science Courses, Core Courses, Advanced Courses, Electives),
Research works, Publications and Seminar [1, $13,14,19,23,27,32,37,46,50,53,57,58,59$, $61,62,65,68,69,73,74,76,78,79,80,83,84$, 87, 88, 100, 107, 115, 132, 134, 135, 137, 149, 156]:

- $\quad$ Plan the Program Educational Objectives, and assess the course outcomes and correlate to the need's analysis.

- $\quad$ Equip the labs and workshops.

- $\quad$ Model the skill development based on the industry needs.

- $\quad$ Ensure the skills to correlate with the industrial tasks.

Subtheme: 1.3 Credit Transfer from MOOCs and Industrial Training

- $\quad$ Collaboration with the industry for training in the desired areas

- Transfer of credits earned through MOOC which meet the program educational objectives

- $\quad$ Transfer the credits earned to the candidate.

Subtheme: 1.4 Industry-Focused, Outcome-Based, and Flexible Curriculum Design Process [137, 134, 135, 136]

- Identify the contextual knowledge.

- Plan analytical works, design, product development, prototype and testing, improvement, planning for mass production and marketing.

- $\quad$ Conduct value analysis.

- Ensure the competencies of the faculty members, if needed, train them.

Subtheme:1.5 Institution -Industry Collaboration [1, $13,24,47,52,53,59,61,83,94,105,120,135$, $159,164,175]$ :

- $\quad$ Industry participation in graduate programs

- Exclusive and customized postgraduate programs for senior executives

- Joint supervision of graduate dissertations which are offered by the industry

- $\quad$ Formation of research consortia and long-term research partnerships to conduct frontier research

- $\quad$ Spin-off companies, patent licensing

- Business incubation services

- Curricula development to improve undergraduate and postgraduate programs

Subtheme: 1.6 Hybrid Courses [174]:

- $\quad$ List the desired courses that are offered by Coursera, edX, WBI etc.

- Determine the skills gained through a test, interview or research proposal. 
Subtheme: 1.7 Industrial Training and Internship [13, $14,24,26,33,52,53]$ :

- $\quad$ Plan needed industrial training.

- If not feasible, implement through virtual industrial training through video, case studies and discussion with alumni or industrial experts.

Subtheme:1.8 Institution-Industry Links [26, 29, 30, $31,32,33,37,42,44,52,95,105,132,135$, $147,159,164,171]$ :

- Inter-organizational arrangements for pursuing collaborative $R \& D$, Including Research Consortia and Joint Projects

- $\quad$ Research based activities commissioned to institutions by industrial clients, including contract research, consulting, quality control, testing, certification, and protype development

- Use of institutions labs and workshops by companies, business incubators, research parks

- Development and commercial exposition exploitation of technologies pursued by faculty and research scholars through a company

- $\quad$ Training of industry executives and employees, on the job training, cooperative training of the students, adjunct faculty, secondment of faculty members

- $\quad$ Transfer of institution generated intellectual property to companies

- Use of codified scientific knowledge within company

- Formation of academic relationships like seminars, and conferences

Subtheme: 1.9 Capstone Projects and Sponsored Research (Dissertation) [72, 74, 120, 129, 132]:

- $\quad$ Develop appropriate capstone projects based on the possible innovative product development, patenting and start-up.

- $\quad$ Encourage dissertation work by undertaking the problems of MSMEs.

- Involve a representative of the company in the team of supervisors.

- Don't allow the submission of commercially made products.

Subtheme: 1.10 Art and Science of Reliable and Valid Measurement of Learners Performance [162]:

- $\quad$ Train the faculty in measurement of student's achievement.

Subtheme: 1.11 Art of Evaluation of Students' Accomplishment [162, 165]:
- $\quad$ Train the faculty in the art of evaluation of student's accomplishment and preparing a recommendation letter.

Subtheme: 1.12 Accreditation of Engineering Program [21, 29]:

- $\quad$ Train the faculty in preparing self-evaluation of the achievement of the department.

- $\quad$ Develop the self-evaluation report for the whole program.

- $\quad$ Submit the self-evaluation to the authorities of the NBA accreditation Agency.

Subtheme: 1.13 Innovations in Curriculum Design and Implementation [10, 76, 140, 149, 166]:

- $\quad$ Bring innovative curriculum design process.

- Implement.

- $\quad$ Review the outstanding innovation.

- $\quad$ Publish the same.

Subtheme: 1.14 Dual Programs

- Encourage the well performing students to register for dual programs (built-in postgraduate programs).

Subtheme: 1.15 Learner Planned Courses [161, 166]:

- $\quad$ Invite themes that are needed by the students.

- $\quad$ Review and appoint a supervisor to monitor.

- $\quad$ Make needed modification.

- $\quad$ Evaluate the outcome and offer grades.

Subtheme: 1.16 Multidisciplinary Programs [155, 161, 179]:

- $\quad$ Encourage minor courses.

- $\quad$ Develop needed courses from other branches.

- Get the approval from the authorities to include them.

Subtheme: 1.17 Disruptions, Challenges and Sustainability [148]:

- $\quad$ Periodically update the courses.

- $\quad$ Add more electives based on the job potentiall advances in the field.

- Introduce new specializations.

- $\quad$ Suggest needed internships.

Subtheme: 1.18 Incorporations of Skills and Competencies due to Industry-4 [172]:

- $\quad$ This is the responsibility of the administrators.

- $\quad$ Study the skill needs.

- Undergo needed training.

- Develop the courses.

- Conduct formative evaluation. 
- Develop the testing facilities and workshop facilities.

- $\quad$ After approval launch the program and courses.

\section{Subtheme: 1.19 Finishing School Programs}

- $\quad$ Suggest additional courses through continuing education.

- $\quad$ Conduct during summer and winter vacation.

- Evaluate the outcome.

- If desired include in the regular curriculum.

Subtheme: 1.20 Cooperative (Sandwich) learning mode [174]:

- $\quad$ Under Apprenticeship scheme, the engineering students are offered stipend for two semesters to undertake on the job training/ industry prescribed practical work.

- $\quad$ Many engineering colleges offer this method.

Subtheme: 1.21 Learn while Earn Scheme

- Many industries allow their employees to undertake two days per week to undergo diploma in manufacturing technology due to the shortage of qualified employees.

- Ashok Leyland implement this scheme in Uttarakhand.

\section{Subtheme: 1. 22 Earn while learn Scheme}

- $\quad$ Some state governments offer production work after $5.00 \mathrm{pm}$ to $8.00 \mathrm{pm}$ to undertake production works for the local industry like BHEL

- $\quad$ The students receive payment for the work completed.

Subtheme: 1.23 Industry Sponsored Postgraduate Programs [30, 32]:

- $\quad$ ECC sponsors a postgraduate program in Construction Technology at IIT Madras and pay the stipend to the students.

\section{THEME- 2: TECHNOLOGY}

Subtheme: 2.1 Educational Technology, Video, YouTube, Audio, and Multimedia

- NITTR at Bhopal, Chandigarh, Chennai, and Kolkata produce educational videos, multimedia learning packages for engineering education.

[www.nitttrc.ac.in, www.nitttrbpl.ac.in, $\quad$ www.nitttr.chd.ac.in, www.nitttrkol.ac.in]

- YouTube has more than 10000 educational video programs and industrial production processes and lead presentation by leaders, managers and researchers which can be freely downloaded by the faculty and students to supplements class lectures.

\section{Subtheme: 2.2 Filliped Classes}

- $\quad$ Curriculum can be designed by incorporating the videos and the students could see them before come for class meetings.

\section{Subtheme: 2.3 Hybrid Programs}

- The MOOCs can be included as a part of classroom activity.

- $\quad$ The faculty members can prescribe NPTEL videos produced by IITs. [www.iitm.ac.in]

- $\quad$ This will provide more skills and competencies to the students.

Subtheme: 2.4 Digital Technology [137]:

- Smart classrooms are equipped with LCD projector, Internet Facility, and Video Conference facility for utilize the online programs and external lectures.

- Webinars are also included in the regular class and as a part of teacher training.

Subtheme: 2.5 Podcasts and Mobile-Learning

- $\quad$ Podcasts could be prescribed as a part of instructional method and the students are can access to them.

- $\quad$ Mobile learning can also be used as a part of instructional delivery.

Subtheme: 2.6 Creativity (Design, Prototype Development, Testing and Improvement, Maintenance) [145]:

- $\quad$ The engineering students could be given a real problem to investigate, analyze, design and produce a prototype.

- Then the prototype has to be tested and improved.

- $\quad$ The intellectual property can be safeguarded through a patent.

- $\quad$ The market potential can be assessed.

- Next it can be offered to a company for mass production.

Subtheme: 2.7 Academic Council, Board of Studies, and Accreditation [139]:

- $\quad$ Every engineering college should constitute an academic council consisting of experts, and senior faculty members.

- They can undertake academic audit of the outcomes like performance of the students, research publications, feedback from the alumni, feedback from the employers, etc. 
- The Academic Council can initiate the development of new programs as chief knowledge officer based on the industrial needs and market potential.

- $\quad$ The Council can review the market potential and suggest to constitute a Board of Studies to plan a program.

- $\quad$ A Board of Study can be constituted for each potential program based on the shell-life and develop a draft program which can be evaluated by an expert committee.

- $\quad$ Later a pilot trial can be implemented in the colleges with necessary resources and trained faculty

- $\quad$ After completing the first summative evaluation, revision, the program could be implemented in other engineering colleges.

Subtheme: 2.8 Tracer Studies (Longitudinal Studies) on the Performance of the graduates in real life and Contribution to Human and knowledge capital by Alumni

- $\quad$ Every year a tracer study can be undertaken by the department.

- $\quad$ Needed questionnaire can be prepared based on the issues.

- Questionnaire can be administered through Internet.

- $\quad$ The feedback and can be analyzed and revision can be undertaken.

\section{THEME-3: EDUCATIONAL ECONOMICS}

Subtheme:3.1 Assessment Human Resources Needs based the Growth of Industries [40]:

- Develop a system to assess the growth of industries in every state based on the starting new enterprises by various actors

- Assess the needs in every branch of specialization, qualification, and experience

- Consult the National Institute of Labour Economics, Research and Development, New Delhi.

- Study the availability and the shortage of needed human resources

Subtheme: 3.2 Educational Economics

- Educational economics centers around the investments, and return.

- $\quad$ Return is due to royalties and service charges through consultancy works.

- $\quad$ Through University Foundation, contributions can be generated from the government, industry, public and alumni.

- $\quad$ The colleges can establish university press and publish excellent books, manuals and other useful materials.
- $\quad$ Fund can be generated by selling them.

- New useful products can be produced and sold in the market similar to selling new and high yielding seeds by agricultural universities.

Subtheme: 3.3: Assessment of Human Resources needed for Globalized Economy [8, 9, 10, 11, 165]:

- $\quad$ The college can establish a consultancy unit in the industrial hubs and corridors.

- Can undertake consultancy work from the industries.

- $\quad$ Can establish a research and development unit in the foreign countries to implement development programs under International Development Agencies like ADB, UNDP, UNESCO, USAID, World Bank, etc.

Subtheme: 3.4 Rewards for Excellent Accomplishment [157, 158, 160, 163]:

- Constitute rewards for excellent accomplishment of the faculty in knowledge capital development, internal revenue generation and service rendered to the community.

- $\quad$ They can bring more revenues through many activities.

Subtheme: 3.5 Entrepreneurship Development [145, 146]:

- $\quad$ Entrepreneurship development is an essential activity of the engineering institutes.

- $\quad$ From day one focus on the areas that can help the graduates to become entrepreneurs.

- Introduce costing principles in the services rendered on transformation of user organizations.

- $\quad$ Try to inculcate the principle of return on investment.

- Develop the principle of acceptable and balanced costing norms.

Subtheme: 3.6 Resources, Capital Expenditure, and Maintenance [129, 133, 139]:

- $\quad$ Create a culture of using the available resources and space for productive and income generation programs.

- $\quad$ Plan and conduct continuing education programs in human capital development and charge reasonable fees.

- Invest the corpus funds in safe markets and mutual funds.

- Watch the earnings and reinvest in high yielding stocks.

- $\quad$ Generate funds for capital expenditure.

- $\quad$ Allocate funds for maintenance. 
- $\quad$ Lease the idle equipment to industry.

Subtheme: 3.7 Periodical Modernization of Labs, Workshops and Infrastructure [113]:

- $\quad$ Allocate funds for periodical maintenance of the equipment.

- $\quad$ Dispose the outdated equipment through public auction.

- Use the workshop to produce salable products.

Subtheme: 3.8 Funds for Faculty Development [151, 168, 169]:

- $\quad$ Generate funds for faculty development.

- $\quad$ Plan in-house faculty development programs.

- Utilize government grants.

- Utilize the programs under IDAs.

Subtheme: 3.9 Return on Investment of Engineering Education

- Assess the return on the investment on the return of tangible improvement.

- $\quad$ Assess the value addition to the reputation.

- $\quad$ Assess the competitiveness of the region due to human capital added.

- $\quad$ Assess the strength of knowledge capital.

Subtheme: 3.10 Corpus Funds and Optimum Utilization of Generated Funds

- $\quad$ Periodically add more to Corpus fund.

- Plan your utilization through Planning Programming Budgeting System (PPBS).

\section{THEME-4: EDUCATIONAL MANAGEMENT}

Subtheme: 4.1 Redesign your Institute as per National Education Policy 2019 [133, 136, 138, 141, 142]:

- $\quad$ Focus on industry sponsored programs.

- $\quad$ Generate Research proposals under National Research Foundation.

- Establish Student Personnel Administration Section.

- $\quad$ Establish Controller of Examination Office

- Introduce continuous internal assessment of students' performance.

Subtheme: 4.2 Higher Education Administration: Define the Role of Board of Governors/ Governing Council/ Trustee [132, 136, 138, $139,140,141,144,147,150,152,153,154$, $157,158,160,163,167,168,169]$ :

- $\quad$ Provide needed information on planning new programs.

- Submit the accomplishment of the students, faculty and departments.
- Constitute a standing committee on the academic decisions for excellence

- $\quad$ Recognize the high-performing teams.

- Create Industry-Institute-Government-Society Partnership Cell.

- Create a Center for Diverse Global Faculty Training and Development Center.

Subtheme: 4.3 Academic Autonomy, Administrative Autonomy, Financial Autonomy and Managerial Autonomy [139, 141, 142, 144, $145,147,151,152,153,154,157,158,160$, $163,167,168,169]$ :

- $\quad$ Provide academic autonomy to the faculty for planning curriculum, undertaking research projects and undertaking training and development.

- Provide freedom to write research papers, books, monographs and plan seminars and conferences

Subtheme: 4.4 Institute-Corporate Universities/ Training \& Development OrganizationsGovernment-National Laboratories- Society Partnership [138, 139, 141, 142, 144, 145, 147, $148,121,153,154,157,158,159,163,164$, 167, 169]:

- Establish linkages for collaborating in knowledge capital

- Establish linkages with professional associations for collaboration

Subtheme: 4.5 Faculty Engagement, Autonomy, and Empowerment [134, 137, 139, 142, 143, 146, $149,151,152,153,154,155,156,158,159$, $160,161,162,163,165,167,168,169,170]$ :

- $\quad$ Plan faculty engagement in Academic Council, Governing Council/Board of Governors, Faculty Forum, Academic Auditing, Board of Studies, Strategic Planning, Self-Assessment of Institute's Performance, Industry-InstituteGovernment-Society-Partnership, Research Committee, Publication Committee, etc.

- Provide autonomy in planning innovative programs and diverse global faculty development, internal revenue generation programs, etc.

- $\quad$ Empower the key performing faculty to take needed leadership in outstanding accomplishment

Subtheme: 4.6 Development of High-Performing and Motivated Faculty-Teams [111, 158,139, 140, $141,142,143,145,147,148,150,151,152,153$, $154,157,158,160,161,163,164,167,168$, 169]: 
- Delegate needed administrative resources to excel in institutional development

- $\quad$ Support high performing teams through funds

- $\quad$ Review the achievement and accountability

- Get periodical feedback on the bottlenecks, constraints, etc.

- $\quad$ Monitor the achievements

- Quantify the outcome

Subtheme: 4.7 Encourage Intrapreneurship [138, $140,143,146,148,150,151,152,153,154$, $155,159,160,167,168,169]$ :

- $\quad$ Communicate the letters of invitation to the faculty members

- $\quad$ Provide needed data to prepare technical and financial data

- $\quad$ Forward the technical and financial proposals with accountability

- $\quad$ Reward as per the norms for sharing the gains

Subtheme: 4.8 Institute- Global Research UniversityInternational Development AgenciesPartnership (I-I-G-C) [136, 137, 138, 140, 142, $147,150,153,154,157,158,159,163,164$ 167, 168]:

- $\quad$ Facilitate the global vision

- Approve the outstanding faculty members to participate in global programs whenever they receive invitation

- $\quad$ Support global programs without any financial commitment

- $\quad$ Create reputation of the institution through global projects

- Facilitate the networking with other global universities for sharing contextual knowledge

Subtheme: 4.9 Institutional Evaluation and Development $[169,168,166,164,163,160$, $161,162,163,154,152,151,150,148,147$, 144]:

- $\quad$ Plan global focus

- $\quad$ Create a vision

- Facilitate to undertake projects under International Development Agencies

- Include new programs in emerging global technology

Subtheme: 4.10 Leadership Development [169, 168, $167,163,160,161,157,154,153,152,150,148$, 147, 143]:

- $\quad$ Support super leadership

- $\quad$ Facilitate the growth of academic leadership in many branches

- $\quad$ Delegate needed autonomy

- Support leadership through research and creating human capital
Subtheme: 4.11 Globalization of Engineering Education and Net Working [7, 8, 9, 10, 23, 30, 47, 62, 72, 124, 136, 138, 141, 142, 158, 163, 167, 169]:

- $\quad$ Compare the global universities academic innovations

- Plan for global outreach through diverse projects

- $\quad$ Create agile institute through anticipating vulnerability, uncertainty, complexity, ambiguity

Subtheme: 4.12 Diverse Global Faculty Development through Various Programs under Bilateral. Agreements between the Governments and Bidding under International Development Agencies (IDAs) [8, 10, 9, 11, 169, 168, 167, $163,160,158,157]$ :

- $\quad$ Support the dedicated initiatives of key performing faculty group

- $\quad$ Encourage bold bidding

- $\quad$ Support equity

- Develop new teams

Subtheme: 4.13 Continuous Capacity Development, Quality Improvement and Efficiency Improvement [157, 158, 154, 132, 165, 168]:

- Facilitate the dynamic growth in knowledge capital

- Focus on capacity development through internal revenue generation

- $\quad$ Focus on quality in all programs and projects

- $\quad$ Fine tune the efficiency improvement

Subtheme: 4.14 Publication Center.

- $\quad$ Establish a publication center

- Bring outstanding monographs in many languages

- $\quad$ Get them reviewed by experts

- $\quad$ Distribute to state libraries

- $\quad$ Bring cheaper editions for students use

Subtheme: 4.15 Eliminating Corruption and Turnaround Mechanism of Poorly Performing Centers, Units and Departments $[168,141,154,142]$ :

- $\quad$ Eliminate corruption in all activities

- $\quad$ Turn around the low performing departments, units and centers

- Jointly plan programs and provide needed resources and staff

Subtheme: 4.16 Creating Centers of Excellence [5, $169,168,167,164,163,160,159,158,157$, 
$154,153,151,150,142,141,140,139,138$,

136, 133, 4, 24, 25, 39]:

- $\quad$ Create Centers of Excellence

- $\quad$ Provide resources and seed funds

- $\quad$ Facilitate the growth through research and new outstanding programs

- $\quad$ Review the growth and eliminate obstacles and bottlenecks

Subtheme: 4.17 Self-Assessment Study, Academic Audit and Impact Studies [169, 165, 163, 160, 157, 156, 155, 154, 153,152, 151, 150,139, 2, $3,4]$ :

- Conduct Self-Assessment Study in each department, center and unit

- $\quad$ Review against the strategic planning mission

- $\quad$ Conduct annual academic audit

- Conduct impact studies and maintain high growth in human capital and knowledge capital

Theme: 5 'FIRE-FIGHTING MODEL' for Closing the Gaps between the Engineering Institute Programs, Competencies of the Graduates and the New Skills and Competencies Need of the Industries due to the Disruptions Causing by Industry-4 through Education-4

The concept of fire-fighting provides a method of improving the engineering institutes, faculty members and graduates from the fast- changing skills and competencies which were not offered earlier. This is similar to safe-guarding the buildings, resources, people from the fastgrowing fires.

Subtheme: 5.1 Impact of New Technology Changing Job Design (Michael Gibbs, 2017) [38, 150,155, 157, 163, 168, 180]:

- Technology complements many tasks, increasing productivity, quality, and innovation

- $\quad$ Big data and machine learning are increasing machines' ability to perform cognitive, physical, and even some social (language) tasks.

- Greater access to data, analysis tools, and telecommunications allows workers to focus more on social interactions, collaboration, continuous improvement, and innovation.

- Technology makes many high-skill jobs more intrinsically motivating, enabling more tasks, skills, and decentralization.

Subtheme: 5.2 Themes about the Future of Jobs Training in the Tech Age (Lee Rainie and Janna Anderson 2017) [34, 1, 15, 17,19,31, 33, 34, 38,44, 64, 124, 125, 127, 131]:
- $\quad$ The training ecosystem will evolve, with a mix of innovation in all education formats.

- Learners must cultivate $21^{\text {st }}$-century skills, capabilities fundamentally change work and attributes.

- New credentialing systems will arise as selfdirected learning expands.

- $\quad$ Training and learning systems will not meet $21^{\text {st }}$ -century needs by 2016.

- Jobs? What jobs? Technological forces will fundamentally change work and the economic landscape.

Subtheme: 5.3 The future of jobs and Jobs training (Lee Rainie and Janna Anderson, 2017) [32, 34,129, 135,137, 139,157,166, 168]:

- A diversifying education and credentialing ecosystem.

- $\quad$ A focus on nurturing unique human skills that artificial intelligence (AI) and machines seem unable to replicate.

Subtheme: 5.4 Role of Engineering Curriculum in Shrinking the Skills Gap (Dora Smith, 2017) $[1,14,17,30,37,40,56]$ :

- $\quad$ The digital enterprise requires graduates who have new, emerging skills that combine traditional theory with digital technology.

- $\quad$ Real-world experience needs to be central tenet of engineering curriculum, and there should be an emphasis on multi-year projects and product lifecycle management (PLM).

- $\quad$ The next generation of products require the next generation of engineers to understand mechanical, electrical and automation systems.

- Universities/institutions should partner with different industry leaders to identify and include the best industrial practices for the new curriculum.

Subtheme: 5.5 Confronting the Fourth Industrial Revolution (evoLLLution.com) [2018] [15, 20, $37,38,41,44,133,139,158,169]$ :

- $\quad$ Produce curious, imaginative, entrepreneurial graduates who can not only work alongside today's machines, but also identify the problems and use cases that will drive subsequent technology waves.

- $\quad$ Through experiential or project-based learning, help students to develop an understanding of the interdependent structures of dynamic systems.

- $\quad$ Inculcate mastery of new literacies such as technology, technology's impact and what humans unique from machines.

- Develop modularized content in an easily accessible format for just-in-time learning. 
Include necessary skills assessment for stackable badges and micro-credentials.

Subtheme: 5.6 Align the Regulatory Environment with $21^{\text {st }}$ Century Realities (EvoLLLution.com, 2019) [20].

- $\quad$ Reinvent higher education and in the process addressing a strategic imperative for nation's workforce

- $\quad$ The $21^{\text {st }}$-century workforce will have to be fully and actively engaged in continuously learning in ways that go beyond the traditional classroom.

- $\quad$ Provide anytime/anyplace access to quality education resources that allow learners to pursue the lifelong learning they need to grow personally and professionally.

- $\quad$ Create resources from just-in-time learning to customized learning paths.

- Generate resources to constantly update the learners' skills.

- Offer competency-based learning

- Create regulation for digital education/ MOOCs

Subtheme: 5.7 Develop a Comprehensive Policy Package with Skills Related Policies as a Cornerstone for thriving in a Digital World (OECD, 2019) [43, 44]:

- $\quad$ To thrive in the digital workplace, workers will need not only digital skills, but also a broad mix of skills including strong cognitive and socioemotional skills.

- High-level ICT skills will be increasingly important in growing occupations linked to new technologies.

- As technology alters the importance of certain jobs in the labor market, governments need to invest in education and training that helps workers to change job or even occupation so that they can benefit from new job opportunities and reduce the risk of losing their jobs.

- Teachers' digital competencies are instrumental to make the most out of new technologies in the classroom.

- $\quad$ Policies need to support lifelong and life-wide learning for all.

- $\quad$ The policy effort needs to be coordinated.

Subtheme: 5.8 Future of Work Skills 2020 [Institute for Future (University of Phoenix Research Institute, 2011) [17, 150, 168]:

- $\quad$ Extreme longevity-increasing global lifespans change the nature of careers

- $\quad$ Trans disciplinary
- Computational World- Massive increase in sensors and processing power make the world a programmable system

- $\quad$ Design mindset

- Superstructure Organizations-Social Technologies drive new forms of production and value creation

- $\quad$ Sense making

- $\quad$ Novel and adaptive thinking

- $\quad$ Social intelligence

- New media literacy

- $\quad$ Computational thinking

- $\quad$ Cognitive load management

- $\quad$ Cross cultural competency

- Virtual collaboration

- $\quad$ Rise of smart machines and systems-Workplace robotics nudge human workers out of rote, repetitive tasks

- New media ecology- New communication tools require new media literacies beyond text

- Globally connected world- Increased global interconnectivity puts diversity and adoptability at the center of organizational operations

\section{Subtheme:5.9 The Entrepreneurial University}

- A central concept to the 'Triple Helix'.

- $\quad$ Takes a proactive stance in putting knowledge to use and creating new knowledge.

- $\quad$ Operates according to an interactive model of innovation.

- As firms raise their technological level, they engage in higher levels of training and knowledge sharing.

- Government acts as a public entrepreneur and venture capitalist, in addition to its traditional regulatory role of the game.

- As universities develop links, they can combine discrete pieces of intellectual property and jointly exploit them

- Innovation has expanded from an internal process within and even among firms to an activity that involves institutions not traditionally thought of as having as having a direct role in innovation such as universities.

- The academic third mission-involvement in socio-economic development, next to traditional missions of teaching and research, is most salient in the Entrepreneurial University.

Subtheme: 5.10 Following the Developments in the Emerging Technology [1, 6, 14, 17, 31, 34, 47]:

- $\quad$ The growth of Machine learning, Artificial Intelligence, IOT, Neural Networks, Deep learning, and other digital technology 
Study the initiatives of global research universities

- $\quad$ Study the contributions to knowledge capital

- $\quad$ Conduct international conferences to deliberate the changes needed

- $\quad$ Develop smart multidisciplinary teams

- Undertake research projects on planning new courses to bridge the gaps of the faculty

- $\quad$ Build new programs and courses in emerging technology

- $\quad$ Conduct formative evaluation at global stage

- $\quad$ Consolidate the outcome

- Improve the resources

- Implement pilot programs

- $\quad$ Study the outcome

- $\quad$ Plan continuous improvement in the courses

- Entrepreneurial university should provide learners/participants with new ideas, competencies and entrepreneurial abilities (Stanford University, 2011).

- Learners/participants/students are not only the new generations of professionals in various scientific disciplines, business, culture etc., but they can also be trained and encouraged to become entrepreneurs and company founders, contributing to economic growth and job creation in a society that needs such outcomes more than ever.

- $\quad$ Entrepreneurial universities should extend their capabilities of educating organizations/ transnational companies through entrepreneurship and incubation programs and new training modules at research parks.

- $\quad$ Entrepreneurial universities should generate new technology and transfer them and became a new source of regional economic development.

\section{Discussion:}

Even though substantially a large number of engineering colleges, state technical universities, deemed universities are producing more than one million graduates per annum, only $15 \%$ of them are employable. A mega model consisting of five themes and subthemes are utilized for assessing the gaps from planning to implementation. Two missing factors are economics, management and firefighting to improve the gaps due to disruptive digital technology and its impact on industry -4 . The outcomes of research works are used to synthesize the efforts needed.

The following are causes for the factors for wide gaps between the curriculum and the industrial needs:
- $\quad$ Lack of qualified teachers

- Inadequate training programs to the faculty members

- $\quad$ Lack modern resources

- $\quad$ Outmoded curricula

- $\quad$ The needs assessments are not carried out

- Improper instructional design

- $\quad$ Evaluation lacks on the high performing skills

- Lack curriculum specific instructional resources

- Lack focus on the industry relevant skills and competencies

- Lack efforts by the management and administrators

- $\quad$ Lack of students' motivation

- $\quad$ Lack of strategic planning and implementation

- $\quad$ Absence of effective industry linkages

- Less participation of the students on the problem-solving activities

- $\quad$ Most of the programs are not accredited

Significant Initiatives under the Five Theme Areas for Improving the State of Affairs are Presented below:

I. Science and Arts of Curriculum Development:

- $\quad$ There is a need for development through needs analysis with active participation of employers, experts and proper formative evaluation;

- $\quad$ Flexibility has to be introduced

- The program educational objectives are to be incorporated

- $\quad$ The course outcomes are to be assessed

- $\quad$ The faculty have to be trained in planning the instructions, and preparing the instructional delivery

- $\quad$ The labs and workshops are to modernized

- The measurements are to be based on the appropriate sampling of the items

- Continuous process of achievement of the students is be implemented

- Industry relevant high order competencies are to be checked through real life projects

- Industrial linkages would facilitate on the job training

- Graduates have to trained through Apprenticeship Scheme

- $\quad$ Credits are to be given whenever the students complete MOOCs

- Guest faculty from the industry has to be included to cover modern practices in emerging technology

- Interdisciplinary courses are to be incorporated based the career needs

- $\quad$ Electives are to be offered to meet the students' career needs

II. Educational Technology 
- $\quad$ Learning aids are to be used based the needs and advancement

- $\quad$ Mobile, learning, filliped classes and internetbased reading are to implemented

- $\quad$ Creativity, problem solving, critical thinking skills are to facilitated

- Academic Council has to established and the outcome has to be reviewed

- $\quad$ Self-assessment for all programs has to be done by the departments and discussed in the Academic Council

- $\quad$ Research works are to be introduced

- $\quad$ Tracer studies are to be undertaken and the curricula and instructional methods are to be fine-tuned periodically.

III. Educational Economics

- $\quad$ Assessment of human resources needs based the growth of industries

- $\quad$ Generating needed capital and creation of adequate corpus fund

- $\quad$ Creating networks with IDAs

- Rewarding the faculty for excellent accomplishment

- Incorporating entrepreneurship development process in the program design

- Resource development and appropriately utilizing

- $\quad$ Periodical maintenance of resources

- Use of Planning, Programming, Budgeting System for starting new programs

IV. Educational Management

- Redesign your institution as per National Education Policy, 2019.

- $\quad$ Constitute a Board of Governors who can guide the planning and implementing various highquality engineering programs to narrow the gaps between the skills and the expectation of employers

- $\quad$ Provide academic autonomy to the faculty members

- Establish Industry-Institute-GovernmentSociety-Partnership Center

- Design appropriate model for faculty engagement in all academic activities

- Develop high-performing faculty team

- $\quad$ Evaluate the performance of the institution and plan further development

- $\quad$ Develop the needed leaders

- Plan effective globalization of engineering education and network with the global universities.

- Develop diverse global faculty development and plan for the support from IDAs

- Improve the capacity, quality and efficiency periodically

- $\quad$ Establish a publication center
- $\quad$ Eliminate corruption

- $\quad$ Create centers of excellence

- Conduct self-assessment study by the departments to identify the gaps and improvement

V. Fire- Fighting Model for Meeting the New Disruptions due to Industry-4

- $\quad$ Assess the impact of digital technology which will change the job design

- $\quad$ Identify the new jobs

- $\quad$ Plan faculty training

- Update curriculum

- $\quad$ Confront the fourth industrial revolution

- Align the regulatory ecosystem to accredit MOOCs

- Develop appropriate policies to meet the challenges of digital disruptions

- $\quad$ Create entrepreneurial university

Conclusions

The proposed mega model is composed for five themes:

- $\quad$ Arts and Science of Curriculum Development

- $\quad$ Educational Technology

- $\quad$ Educational Economics

- $\quad$ Educational Management

- $\quad$ Fire- Fighting Model

The last three themes are essential to narrow the gap between the engineering institutions and industry.

The needs of various engineers at different categories of their career:

- $\quad$ They are expected to use their problem- solving skills in analysis, design, prototype development, testing, planning manufacturing, soft skills, and leadership at entry level. It is desired that the employers need to orient them to undertake desired tasks through in-house training, and evaluate periodically. For every higher post, the company has to plan and offer needed training and development programs.

\section{Contribution of Professional Associations}

- The professional associations train the engineers periodically to meet the advances in the field. Hence, the engineers should undergo such training programs.

\section{Initiatives of Engineering Colleges}

- Most of the engineering colleges train their faculty members through various programs. Hence, the faculty should utilize the opportunities and acquire needed competencies. 


\section{Partnership between Institutes and Industries}

- There is need for establishing a close partnership between the institutes and the industries for collaborating, training, undertaking projects, focused research, sharing the outcomes etc. The advanced institutes can establish consultancy centers and technology focused research parks.

\section{Global Practices}

- $\quad$ Most of advanced countries the linkage is very strong and the whole nation benefits. Indian companies can invest more of research and development through collaboration with the technical universities and autonomous engineering colleges.

\section{Fire-Fighting}

- For meeting the fast- changing needs of disruptions due to Industry-4, the institutes should follow 'fire-fighting process' for safe guarding the graduates through high-end skill development.

This mega model should be further researched to optimize the efforts and maximize the return on investment of engineering education and make the growth of human capital.

Due to many emerging technologies, global competitions and the research and development of MNCs, the gap will persist but continuous efforts are to be taken by engineering institutes to close the gaps. Further outstanding research universities would be leaders in developing new research works which are needed by the industries.

This suggests a far- reaching collaboration between the producer (universities) and consumers (industries/ employers).

\section{References}

1. Abdul Ghani Kanesan Bin Abdullah. (2013). Bridging the Gap between Industry and Higher Education Demands on Electronic Graduates' Competencies. Journal of Electrical and Electronics Engineering (IOSR-JEEE), 8 (1) pp 63-68. www.iosrjournals.org

2. Abdul Hakeem. M. A and Thanikachalam. V. (2014). A Multi-Dimensional Approach in Developing a Framework for Internal Quality Assurance of Second Cycle Engineering Programs, European Scientific Journal, 10(12), pp 414-441.

3. Abdul Hakeem. M.A. and Thanikachalam. V. (2014). Using Analytic Hierarchy Process for
Prioritizing the Dimensions and Determinants of Internal Quality Assurance of Second Cycle Engineering Programs, International Journal of Engineering Research and Development, 10 (4), pp 30-41.

4. Accreditation Board of Engineering and Technologies, Inc. http://www.abet.org/

5. Amabile, T.M., Conti. R., Coon, H., Lazenby, J., and Herron. M. (1996). In: B.M. Staw and L. L. Cumminggs. (Eds). Research in Organizational Behavior, $10 \mathrm{C}$ T: Greenwich, 123167: Jai Press.

6. Ami Zusman. (2918). Challenges Facing Higher Education in the Twenty-First Century. Retrieved from: www.educationanddemocracy.org/Resources/Z usman_pw

7. Anastasia. (2016). How to Set Up a Center of Excellence, Shutterstock.com/garagestock

8. Anita. S and Thanikachalam. V. (2008). Development of Overseas Programs by Indian Engineering and Technical Institutions under GATS, PSG College of Technology, Coimbatore: International Conference on Global Challenges in Engineering and Technical Education and Research.

9. Anita. S and Thanikachalam. V. (2009). Internationalization of Technical Institutes- A Practical Approach, NITTTR-Chennai: International Seminar on Globalization of Indian Engineering Education.

10. Anita. S and Thanikachalam. V. (2011). EastAsian International Collaboration and TrendsA Pathway, NITTTR-Chennai: International Seminar on Globalization of Engineering for Sustenance of Globalization of Engineering Institutions and Networking with International Universities.

11. Anita. S and Thanikachalam. V. (2011). Opportunities for Indian Engineering and Technical Institutes to offer Programmes for Overseas Students and Establishing Overseas Institutes, Journal of Engineering and Technology Education, 4 (2),

12. Azevedo, A., Apfelthaler, G., and Hurst, D., (2012). Competency development in business graduates: An Industry Driven Approach for Examining the Alignment of Undergraduate Business Education with Industry Requirements, The International Journal of Management Education. 10 (2), pp. 12-28.

13. Director, Engineering Accreditation Common. (2015). Engineering Criteria 2000, Retrieved from: https://user.umd.edu/ zhang/41497/abet.html

14. Dora Smith. (2017). Engineering Curriculum's Role in Shrinking the Skills Gap. Retrieved from: 
https//community/plm.automation_siemen.com/t5/Digi tal-Transformations/Engineering-curriculum-srole-shrinking-the-skills-gaps/ba-p/417093

15. Drea Zigarmi, Dobia Houson, Jim Diehl, and David Witt. ( ) .10 Performance Management Process Gaps, Training.

16. Egon G. Guba. (1987). Naturalistic Evaluation, Special Issue: Evaluation Research, pp 1-99, Retrieved from: https://doi.org/10.1002/ev.1451/

17. Emily Abbott et al. (2011). Five Essential Elements of a Successful Twenty-First Century University Corporate Relation Program, Network of Academic Corporate Relations Officers Bench Marking Committee.

18. Engineering Accreditation Commission. (2012). ABET Self-Study Report, 2013-2014 Review Cycle, Baltimore, MD: ABET.

19. Engineering.Com. (2019). What is an EntryLevel Mechanical Engineering Job? Retrieved from: https://www.engineering.com.jobs

20. EvoLLLution.com. (2019) .evalllution.com/managinginstitution/government_legislation/aligningthe-regulatory-environment-with-the- $21^{\text {st }}$ century.

21. European Network for Accreditation of Engineering Education (2017). Retrieved from: https://www.enaee.eu/documements

22. European Trend Chart on Innovation. (2007). Annual Innovation Policy Trends and Appraisal Report, Slovakia.

23. Finch, C.R. and Crunkilton, J.R. Curriculum Development in Career and Technical Education. Boston: Allyn and Bacon, pp 332., Retrieved from: http://oak.ucc.nau.edu/mr/ctee592/Module 1/C urriculum Development An Overview.html.

24. Global Skills. Retrieved from: https://learn.uvm.edu/blog/blog-

business/global-skills-preparing-grads-formarket

25. Global University Network for Innovation (GUNI) (2007). Higher Education in the World 2007. Accreditation for Quality Assurance: What is at stake? GUNI/Palgrave Mac Millan,

26. Government of the Netherlands. (2019). Closing the Gap between Education and Industry

27. Hemalatha. M. and Thanikachalam. V. (2005). Developing Competency Set for Integrating the Human Resource Management in Manufacturing Industry, Indian Journal of Training and Development. 35(2) pp 88-105.

28. Henry Etzkowitz, James Dzisah, Marina Ranga and Chuyan Zhou. (2007). The Triple Helix Model of Innovation- University-IndustryGovernment Interaction, Tech Monitor, pp 14-
23

Retrieved

from:

https://pdfs.semanticschalar.org/4bcc/884ed69

1ff919ae18c947e15bcbaeba08e7f.pdf

29. Jose Guimon. (2013). Promoting UniversityIndustry Collaboration in Developing Countries.

Policy Brief. Washington DC: World Bank

30. Joseph Mutale. (2015). Strong Links between Engineering Faculties and Industry is the Key to Transforming Engineering Education in Africa, Retrieved from: http://africanpolicyreview.com/author/dr_muta le/

31. Julio, A. Pertuze et al. (2010). Best Practices for Industry- University- Collaboration, MIT Sloan Management Review, 51(4). www.sloanreview.mit.edu

32. Katherine Chudoba, Mary Beth Watson and Kevin Crowston. (2012). Innovation in Academic-Industry- Partnerships: Measuring Challenges to Effective Performance, TIM Submission ID 17445, Boston, MA

33. Kazilian, F., Hamzah, R and Bakar, A.R. (2009). Employability Skills Among the Students of Technical and Vocational Training Centers, European Journal of Social Sciences, 9(1) pp 21-26.

34. Lee Rainie and Janna Anderson. (2017). The Future of Jobs and Jobs Training, Retrieved from: https://pewinternet.org/2017/05/03/thefuture-of-jobs-and-jobs-traing/

35. Mathew. B.V. and Thanikachalam. V. (2012). An Analysis of Careers in Building Industry in Asia and the Curriculum of Bachelor's Degree in Civil Engineering. Journal of Engineering and Technology Education, 6(1) pp 1-10.

36. Mathew. B.V. and Thanikachalam. V. (2013). The Critical Needs of an Undergraduate Program in Building Technology and Management, Journal of Engineering, Science and Management Education. 1(4), pp 287-295.

37. Michael G. Dolence. (2003). Learning Centered Curriculum Model: A Structured Framework for Technology Planning, Educause Center for Applied Research, Research Bulletin, Issue. 17, Boulder, Colorado.

38. Michael Gibbs. (2017). How is New Technology Changing Job Design? IZA World of Labor 2017-344. Doi:10.15185/ziawol.344/MichaelGiggs@/Mar ch 2017/wol.iza.org

39. Muthuvellayappan. S and Thanikachalam. V. (2011). An Improved Process for Recruitment, Selection and Training of Employees of the Overseas Indian Industries. Journal of Engineering and Technology Education. 5(2) pp1-13. 
40. Muthuvellaippan. S and Thanikachalam. V. (2012). A Model for Planning Training Programs for Successful Management of International Human Resource Development by Indian Owned MNCs. Journal of Engineering, Science, and Management Education, 5(III), pp 519-528.

41. NACRO Writing Team and Benchmarking Committee. (2011). Five Essential Elements of a Successful Twenty First Century University Corporate Relations. Program Office and Innovation and Entrepreneurship, Economic Development, Administration in Consultation with National Advisory Council on Innovation and Entrepreneurship, USA.

42. National Institute of Labour Economics, Research and Development, www.iamrindia.gov.in

43. OECD, (1999). Redefining Tertiary Education, Paris

44. OECD (2019). Skills Outlook 2019-Thriving in a Digital World. OECD LIBRARY

45. Pandian. A.V. and Thanikachalam. V. (2012) An Integrated Model for Quality Assurance in Management Education, AMET International Journal of Management, Jan-June, 2012, pp 1418.

46. Pasupathi. T.D. and Thanikachalam. V. (2004). A Model for Curriculum Design and Development for Computer Technicians' Education Program. The Indian Journal of Technician Education. 27(2), pp 97-103.

47. Paul Savory. (2005). Details and Description of Industrial Engineering. University of NebraskaLincoln: Digital Commons@University of Nebraska-Lincoln. Retrieved from: https://digitalcommons.unl.edu/imsefacpub/33

48. Ponnusawmy. $\mathrm{M}$ and Thanikachalam. V. (2011). Empowering the Heads of Departments in Engineering Institutions for Sustenance for Globalization, NITTTR-Chennai: International Seminar on Globalization of Engineering and Networking with International Universities.

49. Ponnusawmy. $\mathrm{M}$ and Thanikachalam. V. (2011). Performance Management of Heads of Departments in Self-Financing Engineering Colleges to Meet the Global Engineering Education. 5(1), pp 20-33.

50. Purdue University. (2019). Engineering Education Graduate Competencies. Lafayette, Indiana: School of Engineering Education.

51. Reeni Samuel and Thanikachalam. V. (2011). Environmental Non-Government Organizations in Chennai-Issues, Actions and Impacts- A Study, Philadelphia, PA, USA $: 26^{\text {th }}$ International Conference on Solid Waste Technology and Management, pp 827-838.
52. Renu Khater. (2013). Forging Strategic Business Partnership to Develop the $21^{\text {st }}$ Century Workforce. A Case Study of the University's Undergraduate Petroleum Engineering Program, The Business-Higher Education Forum. www.bhef.com.

53. Reshmi Nair. (2010). Industry Expectations from Engineering Graduates

54. Rosonna Martin, Bryan Maytham, Jennifer Case and Duncan Fraser. (2004). Engineering Graduates' Perceptions of How Well They were Prepared for Work in Industry. European Journal of Engineering Education. 30 (2), pp167-180.DOI:10.1080/0304379050007571

55. Royal Academy of Engineering Study. (2012). http://www.raeng.org.uk/publications/reports/e ngineers-for-africa

56. Sally A. Male. (2010). Generic Engineering Competencies: A Review and Modelling Approach. Education Research and Perspectives, 37 (1) pp 25-51.

57. Sheeba Rani. S. and Thanikachalam. V. (2012) Status Study and the Need for Effective Master Degree Program in Embedded System Technology in South India. Procedia Technology, Retrieved from: www.elesevier.com/locate/procedia, Available online at www.sciencedirect.com, Procedia Technology 00(2011)000-000 Published by Elsevier Ltd.

58. Sheeba Rani. S and Thanikachalam. V. (2013). Enhancing the Employability Quotient of Postgraduates in Embedded Systems: Curriculum based Research Study, International Journal of Technology and Engineering Sciences, 14 (4), pp 287-295.

59. Shukla. O.P. and Suresh Garg. (2016). Skills Requirements for Engineering Graduates: Industry Perspective. IOSR Journal of Business and Management, 18 (10) pp 01-10. DOI: 10.9790/487X-1810040110,

www.iosrjournals.org

60. Srinivasa Rao and Thanikachalam. V. (2005). Assessment of Corporate University with Respect to Indian Industries. Journal of Training and Development. 25(3) pp 49-62.

61. Sivanesan. T. and Thanikachalam. V. (2009). Development of Industry based Curriculum for Manufacturing Technology to Meet the Human Resource Needs of the Chennai Industrial Hub. Journal of Engineering and Technology. 3(2) pp1-15.

62. Sivanesan. T and Thanikachalam. V. (2011) Global Industry-based Flexible Technician Curriculum in Manufacturing Technology. NITTTR Chennai: International Seminar on Global Engineering Institutions Network with International Universities. 
63. Smart Firefighting Project/NIST, Retrieved from: https://www.nist.gov/programsprojects/smart-firefighting-project

64. Srividhya. E and Thanikachalam. V. (2011). A Conceptualization in Enhancing and Globalizing the Computer Science and Information Technology, NITTTR-Chennai: International Seminar on Globalization of Engineering Institutions and Networking with International Universities.

65. Srividhya. E and Thanikachalam. V. (2014). Comparative Study on the Effectiveness of Bachelor of Computer Applications Curriculum, Asian Journal of Research in Social Science and Humanities, 4(v), pp134144.

66. Srividhya. E and Thanikachalam. V. (2014). Evaluation of Effectiveness of B.Sc. Computer Science Curricula, Journal of Engineering Science and Management Education, 7(II), pp124-135.

67. Subbaraj. S and Thanikachalam. V. (2011), Globalizing Mechanical Engineering Curricula, NITTTR-Chennai: International Seminar on Globalization of Engineering Institutions and Networking with International Universities.

68. Subbaraj. S and Thanikachalam. V. (2013). Evaluation of Curricula of B.E./B.Tech. Degree in Mechanical Engineering in Chennai Metropolitan Area Considering the Industrial Needs, Journal of Engineering and Technology, 7(2), pp 19-29.

69. Subbaraj. S. and Thanikachalam. V. (2013). A Study on the Effectiveness of the Present Mechanical Engineering Curricula with Specific Reference to Design Competencies. Journal of Engineering, Science, and Management Education, 6(IV),

70. Sujatha. S and Thanikachalam. V. (2012). An Integrated Model for Institutional Development, 6 (IV)

71. Sujatha. S and Thanikachalam. V. (2013). A Comparative Study between Affiliated Engineering Colleges and Deemed Universities, Journal of Engineering and Technology Education, 6(2) pp 34-50.

72. Swaminathan. T. and Thanikachalam. V. (2010). A Model for Building and Learning Organization. Indian Journal of Training and Development. 30(3). pp 72-82.

73. Thamilarasu. V. and Thanikachalam. V. (2004). A Critical Review of the Focus and Implementation of Three-Year Diploma Program in Civil Engineering in Affiliated Polytechnics. The Indian Journal of Technical Education. 27(2), pp 104-112.

74. Thamilarasu. V. and Thanikachalam. V. (2005) An Integrated Curriculum Model for Three-
Year Diploma Program in Civil Engineering Education. Journal of Engineering Education. 18(3) pp 19-28.

75. Thamilarasu. V. and Thanikachalam. V. (2011). Global Needs of Construction and Building Technologies, NITTTR-Chennai: International Seminar on Globalization of Engineering Institutions and Networking with International Universities.

76. Thanikachalam. V. (1979). Innovations in Curriculum Design in Civil Engineering Subjects, Technical Working Group Meeting, UNESCO's Principal Office for Asian Program for Educational Innovation for Development (APEID) Seoul, Republic of Korea: Korean Educational Development Institute.

77. Thanikachalam. V and Dayanithi. P. (1981). Teacher Training Programs for Science Teachers Through Distance Education, APEID Writing Workshop for Development of Distance Education Teaching Materials for Training of Science Teachers, Program conducted by Technical Teachers Training and Research, Chennai.

78. Thanikachalam. V and Kannapan. D. (1982). Orienting the Engineering Degree Curricula towards Rural Requirements, Seminar on Interaction between Rural Technology and Engineering Curricula, Indian Institute of Technology, Madras: Mechanical Engineering Education Development Center.

79. Thanikachalam. V. (1982). A Case Study on Training of Youth and Adults in Various Productive Skills, Peripatetic Seminar on Vocational Teacher Education, Bangkok, Thailand: APEID-UNESCO.

80. Thanikachalam. V and Ramakrishna Sastri. C. (1982). A Synthesis of Training of Youth and Adults in various Productive Skills, Peripatetic Seminar on Vocational Teacher Education, Bangkok, Thailand: APEID-UNESCO.

81. Thanikachalam. V. and Kannapan. D. (1982). Training of Engineering College Teachers for Effective- Teaching, Seminar on Improvements to Teaching in Engineering Education, Regional Engineering College, Warangal, Andhra Pradesh.

82. Thanikachalam. V. (1982). Design of Industry Oriented Graduate Programs in Engineering and Technology, Seminar on Improvements to Teaching in Engineering Education, Regional Engineering College, Warangal, Andhra Pradesh.

83. Thanikachalam. V. (1982). A Case Study on Training of Youth and Adults in Various Productive Skills through Community Polytechnics, Peripatetic Seminar for Technical Teacher Educators, UNESCO's Asian Program 
for Educational Innovation for Development, Chennai: Technical Teachers Training Institute.

84. Thanikachalam. V. (1983). Newer Teaching Methods in Engineering Education, Annual Conference of Alumni of Education Department, Madras: University of Madras.

85. Thanikachalam. V. (1983). Technology Transfer through Community Polytechnics, Seminar on Technician Education and Rural Development, Valapad, Kerala: Sri Rama Polytechnic

86. Thanikachalam. V. (1983). Curriculum Development for Formal and Non-formal Training Programs for Intensive Rural Development, Seminar on Technician Education and Rural Development, Valapad, Kerala: Sree Rama Polytechnic.

87. Thanikachalam. V. and Sreepathy. V. (1983). Sandwich Courses in the Polytechnics in India, Seminar on Curriculum Innovations in Technical Education, TTTI-Madras: Association of Indian Engineering Industries.

88. Thanikachalam. V. (1988). Planning, Development, Implementation and Evaluation of Engineering Courses through Open Universities for 1990s. Kathmandu, Nepal: First World Congress on Engineering Education.

89. Thanikachalam. V. (1991). Industrial Relevance of Engineering Curricula, Madras, Anna University: Annual Convention of ISTE.

90. Thanikachalam. V. (1991). Strategies for Improving Quality of Instruction based on the Real-World Demands of Engineering Industry. Trivandrum, Kerala: Seminar on Modernization and Quality Improvement of Technician Education.

91. Thanikachalam. V. (1991) An Evaluation of the Existing Civil Engineering Technician Curriculum against Job Potential in Private Sector and Self-Employment in Tamil Nadu. Manila, Philippines: Colombo Plan Staff College for Technician Education.

92. Thanikachalam. V. (1993). Strategies on Planning and Implementation of Multi Point Entry and Credit System. Chennai, Tamil Nadu: Directorate of Technical Education: State Project Implementation Unit of World Bank Assisted Project.

93. Thanikachalam. V. (1993). Assessment of Job Potential and Planning and Development of New Diploma Programs based on the Current and Near Future Demands of Engineering Industry. Directorate of Technical Education, Trivandrum, Kerala: State Project Implementation Unit of World Bank Assisted Project.

94. Thanikachalam. V. (1994). A Study on the Training Needs of Engineers Working in
Government Departments, PWD Chennai: Seminar for Developing Engineers of PWD Staff Training College.

95. Thanikachalam. V. (1995). A Study of the Training Needs of Line Managers from Cement Industry, Dalmiapuram, Tamil Nadu: Regional Training Center, Dalmia Cements (Bharath) Ltd.

96. Thanikachalam. V. (1995) Status of Curriculum Development Centers of State Governments in the Southern States, National Project Implementation Unit, New Delhi: Seminar under World Bank Assisted Project.

97. Thanikachalam. V. (1997). Psychological Foundation of Distance Learning and Continuing Education, Keynote Address, T.T.T.I- Chennai: $35^{\text {th }}$ Conference of Indian Academy of Applied- Psychology.

98. Thanikachalam. V. (1998) Planning and Implementation of Continuing Education Programs. T.T.T.I. Chennai: Fellowship Program under World Bank Assisted Project.

99. Thanikachalam. V. (1998). Models and Strategies for Developing Internal Revenue Generation, T.T.T.I. Extension Center, Hyderabad: Seminar on World Assisted Project, Tech Ed-II.

100. Thanikachalam. V. (1998). Review of Existing Curricula in Environmental Science and Pollution Control in Technician Education in the Southern Region, T.T.T.I-Chennai: Seminar on Better World Environment through Engineering Education and Management.

101. Thanikachalam. V. (1999). Educational Management Information System (EMIS): T.T.T.I. Chennai: MHRD -Planning Meeting

102. Thanikachalam. V. (1999). Guideline Document and DPR Preparation for III Technician Education Project for North Eastern States under World Bank: New Delhi: National Project Implementation Unit.

103. Thanikachalam. V. (1999). Analysis of Problems and Bottlenecks in M. Sc. (Forestry) Program based on the Feedback from the stakeholders, Dehra Dune: Indian Council for Forestry Research and Education. World Bank Assisted Project for the Ministry of Environment and Forest.

104. Thanikachalam. V. (1999). Evaluation of M. Sc. (Forestry) Curriculum offered by Agricultural Universities and Colleges under UGC: Dehra Dune: Indian Council for Forestry Research and Education. World Bank Assisted Project for the Ministry of Environment and Forest.

105. Thanikachalam. V. (1999). Review of Job Potential in Forestry and New Potential in the Next Millennium: Dehra Dune, Indian Council for Forestry Research and Education. 
106. Thanikachalam. V. (1999). Guidelines for Accreditation of Postgraduate Programs of Forestry Colleges with ICFRE, Dehra Dune: ICFRE

107. Thanikachalam. V. (2000). An Analysis for Updating the Existing Civil Engineering Technician Curriculum of The Directorate of Technical Education to Meet the Job Potential in Building Industry and Self-Employment, ISTE Seminar, SRM Engineering College, Tamil Nadu: Builders Association.

108. Thanikachalam. V. (2004). Development of NITTTR as a World Class Institute to Provide Services under GATS. New Frontiers in Education, 34(3).

109. Thanikachalam. V. (2005). Need for Changes in Models for Educational Organizations in Higher Education in India. Perspectives in Higher Education. (21) 4 pp 216-225.

110. Thanikachalam. V. (2005). Strategies to Accelerate Autonomy to High Performing Educational Institutions. New Frontiers in Education. 35(1) pp 14-28.

111. Thanikachalam. V. (2005). An Integrated Approach to Counseling for Professional Growth in Technicians and Engineers. Journal of Engineering Education, XIX (1) pp 43-49.

112. Thanikachalam. V. (2005). Integrated Model for Instructional Design and Delivery in Engineering Programs, The Indian Journal of Technical Education. 28(2) pp 24-37.

113. Thanikachalam. V. (2005). A Model for Sustenance for Institutionalizing World Bank Assisted Project in Technician Education, Port Blair, Andaman and Nicobar Islands: World Bank Assisted Project- Tech. Ed-III.

114. Thanikachalam. V. (2005). Lecturer Induction and Mentoring Program, The Journal of Engineering Education, XIX, (2) pp 50-61.

115. Thanikachalam. V. (2006). Field Driven Geotechnical Engineering Courses for Civil Engineering Students, I.I.T Madras: Indian Geotechnical Engineering Conference.

116. Thanikachalam. V. (2006). A Critical Reappraisal of Leadership and Management Models in Higher Education with a Focus on Indian Scenario, New Frontiers in Education, 34 (1) pp 65-81.

117. Thanikachalam. V. (2006). Human Resource Strategies for Technician Institutes in the North Eastern States, NITTTR-Kolkata: National Seminar on Research Issues in Technical Education.

118. Thanikachalam. V. (2006). Professional Development Programs in Foundation Engineering for the Working Professionals. I.I.T. Madras: Indian Geotechnical Engineering Conference
119. Thanikachalam. V. (2006). Decentralization of Authorities in Planning and Decision Making with respect to Programs and Bidding for Projects. World Bank Institute, WashingtonD.C, USA: Web-based Seminar on Decentralization and Intergovernmental Fiscal Relations.

120. Thanikachalam. V. (2007). Global Business Strategies in Indian Higher Education. Sri Sairam Engineering College, Chennai: International Conference on Global Business Strategy in Competitive Environment.

121. Thanikachalam. V. (2007). The Impact of World Bank Assisted Project in Technician Education III on Tripura State. Narasinghgarh, Tripura: Polytechnic Institute.

122. Thanikachalam. V. (2007). The Impact of World Bank Assisted Project in Technician Education III on the State of Mizoram, Durtlang: Aizawl: Women's Polytechnic.

123. Thanikachalam. V. (2007). The Impact of World Bank Assisted Project in Technician Education III on the State of Meghalaya, Shillong, Meghalaya: Shillong Polytechnic.

124. Thanikachalam. V. (2009). Globalization of Engineering Education in the $21^{\text {st }}$ Century, Chennai: Observers Research Foundation.

125. Thanikachalam. V. (2009). Indian Engineering Education, Challenges and Opportunities, Seminar on Global Engineering Programs, Lafayette, Indiana: Purdue University.

126. Thanikachalam. V. (2009). Globalizing Engineering Education, Albany, NY, USA: State University of New York, Department of Education.

127. Thanikachalam. V. (2009). Planning Global Engineering Programs, NITTTR-Chennai: International Seminar on Globalization of Indian Engineering Education.

128. Thanikachalam. V. (2011). Globalizing Engineering Education, NITTTR Chennai: International Seminar on Globalization of Engineering Institutions and Networking with International Universities.

129. Thanikachalam. V (2012) Modernization of Technician Education in India, A Case Study. Khabarovsk, Russian Federation: Far Eastern University for Humanities.

130. Thanikachalam. V. (2013). Radical Innovation in Human Resource Development, Organization of American States, Washington, D.C., USA: Radical Innovation Summit.

131. Thanikachalam Vedhathri. (2013). Planning Meaning-Centered Technical Teachers Training and Research in India, Retrieved from: www.meaningcentered-technical-teachertraining-institutes-in-india/ 
132. Thanikachalam. V. (2015). Curriculum Design for Industry-Relevant and Interdisciplinary Postgraduate Programs in Engineering and Technology, BMS College of Engineering, Bangalore: Second International Conference on Transformation in Engineering Education.

133. Thanikachalam. V. (2015). Global Convergence to Improve the Internal Quality Assurance for Postgraduate Programs, BMS College of Engineering, Bangalore: Second International Conference on Transformation in Engineering Education.

134. Thanikachalam. V. (2015). Implementation of Outcome- based Postgraduate Programs, [Poster Presentation], BMS College of Engineering, Bangalore: Second International Conference on Transformations in Engineering Education.

135. Thanikachalam. V. (2015). Problems in Curriculum Design for Industry Relevant and Interdisciplinary Programs in Engineering [Keynote Address], NITTTR-Chandigarh: National Conference on Curriculum Innovation and Challenges in Technical Education.

136. Thanikachalam. V. (2016). Transformation in Indian Engineering Education through Academic Autonomy to High Performing Faculty Teams, Journal of Engineering Education Transformations, 30(2), DOI:10.16920/jeet/2016/v30i1/85435

137. Thanikachalam. V. (2016). Planning and Developing Outcome- Based Engineering Curricula to meet the Needs of Fast-Growing Indian Industries, Journal of Engineering Education Transformations, 30(1), DOI:10.16920/jeet/97426

138. Thanikachalam. V. (2016). Strengthening and Sustaining of Industry-Academic-GovernmentPartnership through Continuous Process Improvement, Journal of Engineering Transformations, Special Issue, DOI:10.16920/jeet/2016/v010/85436

139. Thanikachalam. V. (2016). Global Convergence to Internal Quality Assurance to Postgraduate Engineering Programs, Journal of Engineering Transformations, Special Issue, DOI:10.16920/jeet/2015/v0i0/59343

140. Thanikachalam. V. (2016). Intrapreneurship and Innovation in Engineering Education, Journal of Engineering Education Transformations, $\quad 29 \quad$ (3), DOI:10.16920/jeet/v29i3/85204

141. Thanikachalam. V. (2016). Enhancing Institutional Governance beyond the Society's Act of 1860 (Steps to Improve Autonomous Institutes' Administration through Board of Governance), Journal of Engineering Education
Transformations, Special Issue. DOI:10.16920/jeet/2016/v0i0/85534

142. Thanikachalam. V. (2016). Building Institute's Culture and Values to Facilitate Excellent High Performing Institution, Journal of Engineering and Technology Education, 10(1), pp 18-22. DOI:10.16920/jeet/v0i0/

143. Thanikachalam. V. (2016). Enhancing Professional and Soft Skills of the Indian Engineering Graduates, Journal of Engineering and Technology Education, 10(2),1-17. DOI:10.16920/jeet/v0i0/

144. Thanikachalam. V. (2017). Research Cluster in Engineering Education and Human Resource Development, Fourth International Conference on Transformations in Engineering Education, Manipal University, Jaipur, Journal of Engineering Education Transformations, Special Issue, DOI:10.16920/jeet/2017/v0i0/111750

145. Thanikachalam. V. (2017). Entrepreneurship Innovation in Engineering Education, Jaipur Manipal University: Fourth International Conference on Transformations in Engineering Education.

146. Thanikachalam. V. (2017). Entrepreneurship Development in Soil Testing and Consultancy Works in Foundation Engineering, Jaipur, Manipal University: Fourth International Conference on Transformations in Engineering Education.

147. Thanikachalam. V. (2017). Technological Innovations in Support of Make in India, CDIS' Indore: National Conference on Make in IndiaManagement's Role and Perspective.

148. Thanikachalam. V. (2017). Intrapreneurs to Develop Innovations to Meet the Challenges of Make in India, CDIPS, Indore: National Conference on Make in India.

149. Thanikachalam. V. (2017). Strategic Planning of Multidisciplinary M. Tech (HRD) Program, Christ University, Bangalore: National Seminar on SYNTHESIZE.

150. Thanikachalam. V. (2018). Institutional Transformation and Development in Engineering Education to Meet the Volatility, Uncertainty, Complexity, and Ambiguity (VUCA), Madurai- Thiagarajar College of Engineering: Fifth International Conference on Transformations in Engineering Education.

151. Thanikachalam. V. (2018). Educational Management Ecosystem in CEOs for Facilitating the Development of Professional Competencies in CEOs in Higher Education Institutions, Madurai, Thiagarajar College of Engineering: Fifth International Conference on Transformations in Engineering Education. 
152. Thanikachalam. V. (2018). Academic Excellence through Improved and Faculty Engagement, Madurai, Thiagarajar College of Engineering: Fifth International Conference on Transformation on Engineering Education.

153. Thanikachalam. V. (2018). Performance Management and Turnaround Mechanism of Poorly Performing Institutes, Madurai, Thiagarajar College of Engineering: Fifth International Conference on Engineering Education. Journal of Engineering Education Transformations, 22(2).

DOI:10.16920/jeet/2018/v32i2/139500.

154. Thanikachalam. V. (2018). Strategies for Eliminating Corruption in Engineering Education and Fostering Excellence in Human Capital Development, Madurai, Thiagarajar College of Engineering: Fifth International Conference in Engineering Education.

155. Thanikachalam. V. (2018). Enhancing Interdisciplinary Research in Engineering Education (IDREE). Madurai, Thiagarajar College of Engineering: Fifth International Conference on Transformations in Engineering.

156. Thanikachalam. V. (2018). Critical Reviews of Selected Postgraduate Programs on Transportation Engineering against the Needs of Infrastructure Development. Madurai, Theagarajar College of Engineering: Fifth International Conference on Transformations in Engineering Education. Journal of Engineering Education Transformations, 31(4), pp 5-14. DOI:10.16920/jeet/2018/v3i14/125198.

157. Thanikachalam. V. (2018). Desired Educational Ecosystem in the Fast-Growing Educational Institutes in India, Amaravati, AP, SRM University: AP-International Conference on Transformations in Engineering Education. Journal of Engineering Education Transformations, 32(4). DOI:10.16920/jeet/2019/v32i4/145513.

158. Thanikachalam. V. (2018). Advanced Educational System to Undertake International Consultancy Projects in the Engineering Institutes under Global Economy. Amaravati, AP., SRM University: AP-International Conference on Transformations in Engineering Education.

159. Thanikachalam. V. (2018). Bringing Indian Institutions-Industry-Society together. Amaravati-AP, SRM University: APInternational Conference on Transformations in Engineering Education.

160. Thanikachalam. V. (2018). Dynamic Process for Enhancing Engineering Faculty Competence in India. Amaravati, AP, SRM University: AP International Conference on Transformations in Engineering Education.
161. Thanikachalam. V. (2018). Planning Flexible Learner Centered Curricula in Engineering and Technology, Amaravati, AP. SRM University: AP International Conference on Transformations in Engineering Education.

162. Thanikachalam. V. (2018). Valid and Reliable Grading/Evaluation System in Engineering Education, Amaravati, AP, SRM University: AP International Conference on Transformations in Engineering Education.

163. Thanikachalam. V. (2018). Institutional Design to Support an Educational Transformations in Engineering Education. Amaravati, AP, SRM University: AP International Conference on Transformations in Engineering Education.

164. Thanikachalam. V. (2019). Industry-Academia Interaction in Engineering Education through Professional Associations, Hyderabad, Malla Reddy Engineering College, Telangana: Sixth International Conference on Indian Engineering Education.

165. Thanikachalam. V. (2019). Innovative Methods in the Evaluation of Postgraduate Courses, Malla Reddy Engineering College, Hyderabad, Telangana; Sixth International Conference on Transformations in Engineering Education.

166. Thanikachalam. V. (2019). Effect of SelfRegulated Learning Strategies on Engineering Students, Malla Reddy Engineering College, Hyderabad, Telangana: Sixth International Conference on Transformations in Engineering Education.

167. Thanikachalam. V. (2019). Contribution to Diverse Engineering Faculty and to the South Asian Regional Development, Malla Reddy Engineering College, Hyderabad, Telangana: Sixth International Conference on Transformations in Engineering Education.

168. Thanikachalam. V. (2019). Role of Heads of Indian Engineering Colleges in Implementing Digital Technology based Programs, Malla Reddy Engineering College, Hyderabad, Telangana: Sixth International Conference on Transformations in Engineering Education.

169. Thanikachalam. V. (2019). Strategies for Promoting Globally Competitive Engineering Education in India, Malla Reddy Engineering College, Hyderabad, Telangana: Sixth International Conference on Transformations in Engineering Education.

170. The College of Engineering. (2004). Engineering for Developing Communities (EDC), https://mcedc.colorado.edu/

171. The Economist. (2014). Closing the Skills GapCompanies and Colleges Collaborating for Change

172. The National Academies Press -Open Book. (2019). Understanding of the Educational and 
Career Pathways of Engineers. Chapter :3 Factors that Influence the Decision Making of Engineering Students and Graduates. Washington DC: The National Academy of Sciences, Engineering, and Medicine. Retrieved from: www.NAP.edu/10766

173. The National Academic Press- Open Book. (2019). Reshaping the Graduate Education of Scientists and Engineers, Chapter: 5. Conclusions and Recommendations. Washington DC: The National Academy of Sciences, Engineering, and Medicine. Retrieved from: www.NAP.edu/10766

174. Thomas J Perry. (2017). ASME Vision 2030the Voices of 2500 Industry Supervisors, Earlycareer Engineers and ME Departments Heads on the Practice -readiness of Entry-level ME'sand Changes that Happening in ME Degree Programs. Columbus-Ohio: ASEE- 2017 Annual Conference and Exposition.

175. Today's K. I. Sawyer a model for development, Retrieved from: www.michiganbuildingtrades.org/newspaper/t odays-k-i

176. UIDP Projects. (2013). 10 Case Studies of High-Return University-Industry Collaborations.

177. Using Fire Models to Understand Fire Behavior-Fire Rescue. Retrieved from: https://www.firerescuemagazine.com/.../usingfire-modls-to-understand-firebehavior.html

178. Umar Farooq. ( ). Steps to Training Needs Analysis Process.

179. Yale-School of Engineering and Applied Science. (2019). Research areas are primarily organized by department, through nearly every effort included interdisciplinary collaborations. Yale engineering faculty members are world leaders of critical importance to solving $21^{\text {st }}$ century problems.

180. World Economic Forum. (Alex Gray, 2016). Retrieved from: https://weforum.org/agenda/2016/01/the-10skills-you-need-to-thrive-in-the-fourthindustrial-revolution/

181. Zaharim, A., Yusoff, Y.M., Omar, M. Z., Mohamed, A. and Muhamad, N. (2010). Employers' Perceptions and Expectation toward Engineering Graduates: A Study Case, Proceedings of the $6^{\text {th }}$ WSEAS International Conference on Engineering Education. 